\title{
UPOWAŻNIENIE DO PRZETWARZANIA DANYCH OSOBOWYCH
}

\section{Wstęp}

Zgodnie z przepisem art. 29 ogólnego rozporządzenia o ochronie danych ${ }^{1}$ przetwarzanie danych osobowych powinno być dokonywane przez osoby działające $\mathrm{z}$ upoważnienia administratora lub podmiotu przetwarzającego i wyłącznie na polecenie administratora, chyba że wymaga tego prawo. Brzmienie wskazanego przepisu jest niejednoznaczne, przepis jest różnie interpretowany, z jego treści wyciągane są odmienne wnioski. Pociąga to za sobą istotne wątpliwości praktyczne, które można sprowadzić do pytania: czy konieczne jest nadawanie upoważnień do przetwarzania danych osobowych, czy wystarczy, że osoba dokonująca czynności przetwarzania będzie działać na polecenie administratora bez formalnie nadanego upoważnienia? Przy analizie konstrukcji prawnej upoważnienia nasuwają się kolejne pytania: jaka powinna być treść upoważnienia, w jakiej formie upoważnienie powinno być nadawane, przez jaki czas upoważnienie obowiązuje, kiedy wygasa i w jaki sposób może być odwołane.

* Dr hab., prof. Katolickiego Uniwersytetu Lubelskiego Jana Pawła II, Centrum Prawa Technologii Informacyjnych i Ochrony Danych; e-mail: paf@kul.pl, https://orcid. org/0000-0002-4293-1917.

1 Rozporządzenie Parlamentu Europejskiego i Rady (UE) nr 2016/679 z dnia 27 kwietnia 2016 r. w sprawie ochrony osób fizycznych w związku z przetwarzaniem danych osobowych i w sprawie swobodnego przepływu takich danych oraz uchylenia dyrektywy 95/46/WE (ogólne rozporządzenie o ochronie danych), Dz. Urz. UE L 119 z 4.05.2016, s. 1-88, ze sprostowaniem (dalej: rozporządzenie 2016/679). 
W niniejszym artykule przedstawiona zostanie geneza obowiązku nadawania upoważnienia do przetwarzania danych i regulacja prawna dotycząca upoważnienia w poprzednio obowiązujących przepisach o ochronie danych osobowych. Zaprezentowana zostanie również wykładnia obecnie obowiązujących unijnych przepisów dotyczących upoważnienia, ze szczególnym uwzględnieniem podnoszonych w piśmiennictwie przedmiotu wątpliwości, a następnie omówione zostaną krajowe przepisy szczególne przewidujące obowiązek nadawania upoważnienia.

\section{Geneza obowiązku nadawania upoważnienia}

W przepisach dyrektywy 95/46/WE², która przez ponad 20 lat była podstawowym aktem normatywnym wyznaczającym europejskie standardy ochrony danych osobowych i której przepisy podlegały implementacji do wewnętrznego porządku prawnego państw członkowskich Unii Europejskiej, obowiązek nadawania upoważnienia do przetwarzania danych osobowych nie został wprost określony. Jednak w polskiej wersji językowej art. 16 dyrektywy 95/46/WE angielskie sformułowanie person acting under the authority of the controller przetłumaczono jako „osoba działająca z upoważnienia administratora”, natomiast angielskie określenie on instructions from the controller przetłumaczono jako "na polecenie administratora”, a cały przepis odnoszący się do poufności przetwarzania danych w polskim tłumaczeniu brzmiał następująco: „Żadna osoba działająca z upoważnienia administratora danych lub przetwarzającego, włączając samego przetwarzającego, który ma dostęp do danych osobowych, nie może przetwarzać ich bez polecenia administratora danych, chyba że wymaga tego prawo" i odbiegał znaczeniowo od wersji oryginalnej3.

2 Dyrektywa Parlamentu Europejskiego i Rady 95/46/WE z dnia 24 października 1995 r. w sprawie ochrony osób fizycznych w zakresie przetwarzania danych osobowych oraz swobodnego przepływu tych danych, Dz. Urz. UE L 281 z 23.11.1995, s. 31-50; Dz. Urz. UE polskie wyd. spec.: rozdz. 13, t. 15, s. 355-374 z późn. zm., uchylona.

3 Brzmienie angielskiej wersji przepisu było następujące: „Any person acting under the authority of the controller or of the processor, including the processor himself, who has access to personal data must not process them except on instructions from the controller, unless he is required to do so by law". W wersji niemieckiej przepis ten miał następujące brzmienie: „Personen, die dem für die Verarbeitung Verantwortlichen oder dem 
Wydaje się, że bardziej trafnym przekładem byłoby sformułowanie, że osoba ma działać pod zwierzchnictwem administratora i zgodnie z jego instrukcjami.

Prawodawca polski, dokonując implementacji dyrektywy 95/46/WE, oparł się na jej polskim tłumaczeniu i w art. 37 ustawy z dnia 29 sierpnia 1997 r. o ochronie danych osobowych ${ }^{4}$ sformułował wprost wymóg dopuszczenia do obsługi systemu informatycznego oraz urządzeń wchodzących w jego skład, służących do przetwarzania danych, jedynie osób posiadających upoważnienie nadane przez administratora. Na tym tle nasuwała się wątpliwość, czy konstrukcja przyjęta przez polskiego prawodawcę była zgodna z przepisem dyrektywy 95/46/WE, przy wskazanych powyżej rozbieżnościach. Zasadne było jednak przyjęcie, że prawodawca krajowy skorzystał w tym zakresie z możliwości odmiennego ukształtowania konstrukcji prawnej (w ramach swobody implementacyjnej) i uznał upoważnienie za jeden $\mathrm{z}$ mechanizmów służących zabezpieczeniu prawidłowości przetwarzania danych. Prawodawca dokonał zmiany wskazanego powyżej przepisu w roku 2004, odnosząc obowiązek nadawania upoważnień do przetwarzania danych osobowych, a nie tylko do obsługi systemu informatycznego, faktycznie znacznie rozszerzając zakres tego obowiązku. Taka konstrukcja prawna nie była zasadniczo krytykowana, $\mathrm{w}$ niektórych publikacjach wyrażano nawet opinie, że jest ona $\mathrm{w}$ pełni zgodna z przepisem art. 16 dyrektywy 95/46/WE5. Obowiązek nadawania upoważnień do przetwarzania danych osobowych został w krajowych przepisach powiązany z przewidzianym w art. 39 ust. 1 uodo 1997 wymogiem prowadzenia ewidencji osób upoważnionych oraz wymogiem zachowania $\mathrm{w}$ tajemnicy treści przetwarzanych danych i sposobów ich zabezpieczenia.

W praktyce obowiązek nadawania indywidualnych upoważnień do przetwarzania danych osobowych był realizowany powszechnie. Niekiedy jednak podejmowano próby kwestionowania tego obowiązku

\footnotetext{
Auftragsverarbeiter unterstellt sind und Zugang zu personenbezogenen Daten haben, sowie der Auftragsverarbeiter selbst dürfen personenbezogene Daten nur auf Weisung des für die Verarbeitung Verantwortlichen verarbeiten, es sei denn, es bestehen gesetzliche Verpflichtungen".

4 Ustawa z dnia 29 sierpnia 1997 r. o ochronie danych osobowych, tekst jednolity: Dz. U. z 2016 r. poz. 922 z późn. zm. (dalej: uodo 1997).

5 Np. A. Drozd, Ustawa o ochronie danych osobowych. Komentarz. Wzory pism i przepisy, wyd. 3, Warszawa 2007, s. 266.
} 
w sytuacji, gdy zakres uprawnień do przetwarzania danych wynikał wprost z przepisów prawa. Jedna z tego rodzaju prób zakończyła się sukcesem - w przypadku prokuratorów Naczelny Sąd Administracyjny orzekł, że „prokurator legitymujący się ustawowym upoważnieniem i limitowany normami proceduralnymi nie musi posiadać odrębnego upoważnienia do dostępu do danych osobowych"6. W piśmiennictwie przedmiotu wskazywano, że obowiązek nadawania upoważnień do przetwarzania danych nie dotyczył również organu nadzorczego (wówczas: Generalnego Inspektora Ochrony Danych Osobowych) i osób, które z jego upoważnienia prowadzą kontrolę przestrzegania przepisów o ochronie danych, ponieważ przepisy uodo 1997 wyraźnie uprawniają te osoby m.in. do wglądu do danych mających bezpośredni związek z przedmiotem kontroli ${ }^{7}$ Odnosi się to również do innych osób prowadzących kontrolę na podstawie przepisów prawa (np. kontrolerów Najwyższej Izby Kontroli), gdyż osoby te działają nie w imieniu i na rzecz administratora danych, ale organów, w imieniu których prowadzą kontrolę 8 .

Przepisy uodo 1997 nie określały, jaka ma być treść ani forma upoważnienia, jednak w praktyce stosowania ustawy powszechnie przyjmowano, że upoważnienie powinno mieć charakter indywidualny, wskazujący na zakres uprawnień do przetwarzania danych oraz być nadawane $\mathrm{w}$ formie pisemnej.

Upoważnienie do przetwarzania danych osobowych uznawane było za istotny element limitujący zakres dopuszczalnego przetwarzania danych, pozwalający - w przypadku pojawienia się wątpliwości - na dokonanie oceny, czy określone czynności przetwarzania mieszczą się w tym zakresie. W jednym z orzeczeń ${ }^{9}$ Sąd Najwyższy uznał, że przekroczenie przez pracownika zakresu udzielonego przez administratora upoważnienia do przetwarzania danych osobowych stanowi naruszenie podstawowych obowiązków pracowniczych oraz naruszenie przepisów o ochronie danych osobowych i może być podstawą do rozwiązania umowy o pracę bez zachowania okresu wypowiedzenia.

\footnotetext{
6 Wyrok NSA z dnia 21 grudnia 2006 r., I OSK 1279/05.

7 Szerzej na ten temat zob. J. Barta, P. Fajgielski, R. Markiewicz, Ochrona danych osobowych. Komentarz, Warszawa 2015, s. 572 i n.

8 M. Sakowska-Baryła, Prawo do ochrony danych osobowych, Wrocław 2015, s. 187.

9 Wyrok SN z dnia 4 kwietnia 2017 r., II PK 37/16.
} 


\section{Upoważnienie w świetle rozporządzenia 2016/679}

Podobnie jak w dyrektywie 95/46/WE, również w ogólnym rozporządzeniu o ochronie danych nie został wyraźnie określony obowiązek nadawania upoważnień do przetwarzania danych. Przepis art. 29 rozporządzenia 2016/679, który w polskiej wersji językowej został zatytułowany „Przetwarzanie z upoważnienia administratora lub podmiotu przetwarzającego", stanowi, że "podmiot przetwarzający oraz każda osoba działająca z upoważnienia administratora lub podmiotu przetwarzającego i mająca dostęp do danych osobowych przetwarzają je wyłącznie na polecenie administratora, chyba że wymaga tego prawo Unii lub prawo państwa członkowskiego". Można zauważyć, że polskie tłumaczenie ponownie jest niezbyt precyzyjne i powtarza sformułowania odnoszące się do upoważnienia i polecenia administratora, podczas gdy w brzmieniu przyjętym w innych językach chodzi raczej o działanie pod zwierzchnictwem (ang. under the authority) i zgodnie z instrukcjami administratora (ang. on instructions from the controller $)^{10}$. $\mathrm{O}$ ile $\mathrm{w}$ ramach implementacji dyrektywy prawodawca krajowy dysponuje pewnym zakresem swobody, co może usprawiedliwiać odmienne ukształtowanie niektórych rozwiązań prawnych, pod warunkiem, że założone przez prawodawcę unijnego cele zostały wskutek implementacji osiągnięte, o tyle w przypadku rozporządzenia, które jest stosowane bezpośrednio (bez przenoszenia zawartych tam konstrukcji prawnych do krajowego porządku prawnego), przyjęte $w$ polskiej wersji językowej odmienności budzą zastrzeżenia.

W piśmiennictwie przedmiotu można zauważyć dwa odmienne sposoby interpretacji przepisu art. 29 rozporządzenia 2016/679. Pierwszy bazuje na literalnej wykładni przepisu w polskiej wersji językowej i nawiązuje do konstrukcji upoważnienia przewidzianej w poprzednich krajowych przepisach. Podkreślenie „działania z upoważnienia administratora” prowadzi do wniosku o obowiązku udzielania upoważnień osobom, które mają przetwarzać dane na polecenie administratora ${ }^{11}$. Drugi sposób wykładni

10 W angielskiej wersji językowej przepis art. 29 rozporządzenia 2016/679 nosi tytuł „Processing under the authority of the controller or processor”, a jego treść jest następująca: „The processor and any person acting under the authority of the controller or of the processor, who has access to personal data, shall not process those data except on instructions from the controller, unless required to do so by Union or Member State law".

11 Por. M. Krzysztofek, Ochrona danych osobowych w Unii Europejskiej po reformie. Komentarz do rozporzadzenia Parlamentu Europejskiego i Rady (UE) 2016/679, Warszawa 2016, 
akcentuje działanie na polecenie administratora jako istotę obowiązku wynikającego z art. 29 rozporządzenia 2016/679, z czego wyprowadzany jest wniosek o braku obowiązku nadawania upoważnieńn ${ }^{12}$. Na poparcie prezentowanych interpretacji podawane są także inne argumenty ${ }^{13}$.

Analizowany problem można rozpatrywać również z perspektywy ogólnych zasad przetwarzania i ochrony danych. Prawodawca unijny, nakładając ogólny obowiązek przetwarzania danych osobowych w sposób zapewniający odpowiednie bezpieczeństwo danych osobowych (w tym ochronę przed niedozwolonym lub niezgodnym z prawem przetwarzaniem oraz przypadkową utratą, zniszczeniem lub uszkodzeniem) za pomocą odpowiednich środków technicznych lub organizacyjnych (art. 5 ust. 1 lit. f rozporządzenia 2016/679) pozostawił administratorowi swobodę wyboru odpowiednich zabezpieczeń, wymagając jednak zapewnienia rozliczalności, a więc nakładając na administratora wymóg, aby był on w stanie wykazać przestrzeganie zasad. Z tej perspektywy, mając na uwadze również potrzebę uwzględnienia istoty obowiązku wynikającego z przepisu, zasadne wydaje się uznanie, że prawodawca unijny przewidział jedynie ogólny obowiązek działania pod kierownictwem i zgodnie z instrukcjami administratora, nie nałożył zaś na administratora obowiązku nadawania indywidualnych upoważnień. To, w jaki sposób administrator będzie dokumentował fakt spełnienia wymogów (czy nada upoważnienia, czy w inny sposób będzie wykazywał, że osoby działają pod jego zwierzchnictwem i zgodnie z jego instrukcjami), prawodawca unijny pozostawił decyzji administratora.

Interpretacja art. 29 rozporządzenia 2016/679 idąca w kierunku uznania obowiązku nadawania pisemnych upoważnień spotkała się z krytyką także w praktyce - jako nieznajdująca odzwierciedlenia w przepisach

\footnotetext{
s. 215; M. Cwener, Nowe obowiązki dokumentacyjne związane z przetwarzaniem danych osobowych, w: Ogólne rozporzadzenie o ochronie danych osobowych. Wybrane zagadnienia, red. M. Kawecki, T. Osiej, Warszawa 2017, s. 107-108; P. Litwiński, P. Barta, M. Kawecki, Rozporzqdzenie UE w sprawie ochrony osób fizycznych w zwiazku z przetwarzaniem danych osobowych i swobodnym przeptywem takich danych. Komentarz, red. P. Litwiński, Warszawa 2018, s. 489.

12 Por. K. Witkowska-Nowakowska, Komentarz do art. 29, w: RODO. Ogólne rozporzadzenie o ochronie danych. Komentarz, red. E. Bielak-Jomaa, D. Lubasz, Warszawa 2018, s. 659; K. Wygoda, Komentarz do art. 29, w: Ogólne rozporządzenie o ochronie danych osobowych. Komentarz, red. M. Sakowska-Baryła, Warszawa 2018, s. 334.

13 Na temat wykładni przepisu art. 29 por. także P. Fajgielski, Ogólne rozporządzenie o ochronie danych. Ustawa o ochronie danych osobowych. Komentarz, Warszawa 2018, s. 349 i n.
} 
ogólnego rozporządzenia o ochronie danych. Podniesiono m.in. argument, że praktyka nadawania pisemnych upoważnień do przetwarzania danych nie jest stosowana systemowo w innych krajach członkowskich UE; podano $\mathrm{w}$ wątpliwość skuteczność oddziaływania upoważnienia jako szczególnego środka bezpieczeństwa mającego na celu zabezpieczenie przed nadużyciami oraz niezgodnym z prawem dostępem lub przekazywaniem danych; a także wskazano na kolizję z zasadą adekwatności doboru środków bezpieczeństwa przez administratora oraz z podejściem opartym na analizie ryzyka ${ }^{14}$.

Reasumując powyższe rozważania, należy przyjąć, że z brzmienia przepisu art. 29 rozporządzenia 2016/679 nie wynika obowiązek nadawania pisemnego, indywidualnego upoważnienia do przetwarzania danych, a jedynie wymóg zapewnienia, aby osoby przetwarzające dane wykonywały czynności pod nadzorem i zgodnie z instrukcjami administratora (bądź podmiotu przetwarzającego). To, czy administrator (i odpowiednio podmiot przetwarzający) będzie nadawać pisemne upoważnienia, czy też w inny sposób dokumentować spełnienie wymogu przetwarzania danych pod nadzorem i zgodnie $\mathrm{z}$ instrukcjami, prawodawca unijny pozostawił decyzji administratora (i podmiotu przetwarzającego).

\section{Upoważnienia $\mathrm{w}$ przepisach szczególnych}

Stan prawny w zakresie obowiązku nadawania upoważnień do przetwarzania danych osobowych zmienił się zasadniczo wskutek uchwalenia ustawy wdrażającej unijne rozporządzenie o ochronie danych ${ }^{15}$. Na mocy tego aktu dokonano nowelizacji 162 ustaw, wprowadzając do 60 przepisów szczególnych wymóg nadawania pisemnych upoważnień do przetwarzania danych osobowych. Analiza zmienionych przepisów pozwala stwierdzić, że prawodawca krajowy wprowadził dodatkowy (względem

14 P. Wojczys, Pisemne upoważnienia do przetwarzania danych, Informacja w Administracji Publicznej 2019, nr 9, s. 40-41.

15 Ustawa z dnia 21 lutego 2019 r. o zmianie niektórych ustaw w związku z zapewnieniem stosowania rozporządzenia Parlamentu Europejskiego i Rady (UE) 2016/679 z dnia 27 kwietnia 2016 r. w sprawie ochrony osób fizycznych w związku z przetwarzaniem danych osobowych i w sprawie swobodnego przepływu takich danych oraz uchylenia dyrektywy 95/46/WE (ogólne rozporządzenie o ochronie danych), Dz. U. z 2019 r. poz. 730. 
przewidzianych w ogólnym rozporządzeniu o ochronie danych) wymóg nadawania upoważnień do przetwarzania danych osobowych w dwóch grupach przypadków:

1) w przypadku ograniczenia niektórych obowiązków (np. informacyjnych) na podstawie art. 23 rozporządzenia 2016/679;

2) w przypadku wprowadzenia podstaw do przetwarzania szczególnych kategorii danych (w oparciu o art. 9 ust. 3 rozporządzenia 2016/679).

Fakt wprowadzenia w przepisach szczególnych obowiązku nadawania upoważnień potwierdza przedstawioną powyżej wykładnię art. 29 rozporządzenia 2016/679, ponieważ jeżeli obowiązek taki wynikałby z przepisów ogólnego rozporządzenia, to wprowadzanie tego rodzaju obowiązku w przepisach szczególnych byłoby zbędne. Uchwalenie przepisów szczególnych w tym zakresie ogranicza swobodę administratora poprzez nałożenie na niego wyraźnego obowiązku nadawania upoważnień do przetwarzania danych.

Typowa konstrukcja przepisu przewidującego obowiązek nadawania upoważnienia jest następująca:

„Dane osobowe [...] podlegają zabezpieczeniom zapobiegającym nadużyciom lub niezgodnemu z prawem dostępowi lub przekazaniu polegającym co najmniej na:

1) dopuszczeniu do przetwarzania danych osobowych wyłącznie osób posiadających pisemne upoważnienie wydane przez administratora danych;

2) pisemnym zobowiązaniu osób upoważnionych do przetwarzania danych osobowych do zachowania ich w tajemnicy".

Prawodawca wykorzystał tę konstrukcję w przepisach 35 ustaw, w pozostałych ustawach zmienionych, wprowadzając konstrukcje nieco odmienne. Ustawodawca uznał obowiązek nadawania upoważnień za jeden z rodzajów "zabezpieczeń zapobiegających nadużyciom lub niezgodnemu z prawem dostępowi lub przekazaniu danych".

Brzmienie pierwszego punktu stanowi powtórzenie sformułowania zawartego wcześniej w art. 37 uodo 1997 z tą jedynie różnicą, że przepisy szczególne dookreślają, iż upoważnienie powinno być „pisemne”. Można zatem uznać, że intencją prawodawcy było nawiązanie do ukształtowanej w naszym kraju w ostatnich kilkunastu latach praktyki nadawania indywidualnych upoważnień do przetwarzania danych. Jednak przyjęty wcześniej obowiązek nadawania upoważnień miał charakter powszechny i stanowił regułę, natomiast obowiązek nadawania upoważnień wynikający 
z przepisów szczególnych ma charakter wyjątkowy i stanowi odstępstwo od zasady, zgodnie z którą dobór odpowiednich zabezpieczeń należy do zadań administratora. Pociąga to za sobą konieczność sprawdzenia przez administratora, czy przepis szczególny nie nakłada na niego obowiązku nadania upoważnienia.

Poważne wątpliwości budzi użyte w przepisach szczególnych sformułowanie „pisemne upoważnienie”. Takie brzmienie przepisu nie wskazuje jednoznacznie, czy ustawowy wymóg odnosi się do zachowania formy pisemnej (w znaczeniu art. 78 k.c. ${ }^{16}$ ), a więc wymaga złożenia podpisu administratora (lub osoby przez niego upoważnionej do wydawania upoważnień) pod treścią upoważnienia, czy też za wystarczającą można uznać formę dokumentową (o której mowa w art. $77^{2}$ k.c.), a więc czy wystarcza nadanie upoważnienia $\mathrm{w}$ postaci dokumentu (rozumianego jako nośnik informacji umożliwiający zapoznanie się z jej treścią) w sposób umożliwiający ustalenie osoby nadającej upoważnienie. Brak wyraźnego odniesienia do formy pisemnej można uznać za złagodzenie przez prawodawcę wymogów formalnych, niemniej mając na uwadze określony przepisami wymóg pisemności należy przyjać, że administrator powinien nadawać upoważnienia, których treść byłaby utrwalona na piśmie i pozwalała stwierdzić: komu, kiedy, w jakim zakresie i przez kogo upoważnienie zostało udzielone. W praktyce oznacza to możliwość dokonania wyboru między tradycyjnymi papierowymi upoważnieniami a upoważnieniami elektronicznymi (w tym również prowadzonymi w systemie informatycznym). Jednakże wymogi zawarte w dalszej części przepisu wskazują, że w praktyce nadal będą dominować upoważnienia $\mathrm{w}$ postaci papierowej z uwagi na powiązanie upoważnienia ze zobowiązaniem do zachowania tajemnicy (o czym szerzej poniżej).

Za niefortunne należy uznać użyte $\mathrm{w}$ tym przepisie sformułowanie „zabezpieczeniom [...] polegającym co najmniej na", które może sugerować, że nadanie upoważnienia stanowi minimalne, wymagane prawem zabezpieczenie przetwarzanych danych, podczas gdy w świetle ogólnego rozporządzenia administrator powinien przeprowadzić analizę ryzyka i wdrożyć takie zabezpieczenia, jakie uzna za wystarczające dla zapewnienia skutecznej ochrony, natomiast nadanie upoważnień powinno być

16 Ustawa z dnia 23 kwietnia 1964 r. - Kodeks cywilny, Dz. U. z 2019 r. poz. 1145 z późn. zm. 
traktowane jako jeden z różnych rodzajów zabezpieczeń - jeśli jedyny, to z pewnością nie wystarczający.

Przepisy nakładające obowiązek nadawania upoważnień nie regulują kwestii zakresu informacji, jakie powinny być zawarte $\mathrm{w}$ upoważnieniu. Uwzględniając istotę upoważnienia, można przyjąć, że w treści upoważnienia powinno się znaleźć: wskazanie osoby upoważnionej (imię, nazwisko i stanowisko), określenie zakresu upoważnienia (przy czym zakres nie powinien się odnosić do zbiorów danych, ale do procesów przetwarzania ${ }^{17}$ ), wskazanie daty nadania upoważnienia i terminu jego ważności oraz wskazanie osoby, która nadała upoważnienie.

Obowiązek nadania upoważnienia został powiązany w wielu przepisach z wymogiem pisemnego zobowiązania osób upoważnionych do zachowania danych $w$ tajemnicy. Tego rodzaju konstrukcja prawna ma stanowić dodatkowe zabezpieczenie przetwarzanych danych. Może ona jednak sugerować, że osoby, które nie mają upoważnienia i nie zobowiązały się do zachowania danych w tajemnicy, mogą ujawniać dane osobowe. Jest to wnioskowanie nieprawidłowe, gdyż osoby dopuszczone do przetwarzania danych mogą działać jedynie pod zwierzchnictwem i zgodnie $\mathrm{z}$ instrukcjami administratora, a na administratorze ciąży obowiązek przetwarzania danych w sposób zapewniający ich bezpieczeństwo, w tym ochronę przed niedozwolonym lub niezgodnym z prawem przetwarzaniem (rozumiany również jako wymóg zachowania danych w poufności), który stanowi jedną z ogólnych zasad ochrony danych (wyrażoną w art. 5 ust. 1 lit. f rozporządzenia 2016/679), ponadto administrator ma obowiązek zapewnić odpowiednie zabezpieczenia m.in. przed nieuprawnionym ujawnieniem lub nieuprawnionym dostępem do danych osobowych.

Prawodawca w typowej konstrukcji uznał, że najpierw należy nadać upoważnienie do przetwarzania danych osobowych, a następnie odebrać zobowiązanie do zachowania danych $\mathrm{w}$ tajemnicy. Tego rodzaju rozwiązanie budzi zastrzeżenia, można się zastanawiać, czy lepszym rozwiązaniem nie jest konstrukcja prawna przyjęta w przepisach odnoszących się do rzeczników ${ }^{18}$, polegająca na przyjęciu odwrotnej kolejności i uznaniu,

17 Odwołanie do zbiorów było typowe na gruncie uodo 1997, natomiast w rozporządzeniu 2016/679 zmienił się punkt odniesienia i zakres przetwarzania powinien dotyczyć procesów przetwarzania danych.

18 Por. art. 17c ust. 3 ustawy z dnia 15 lipca 1987 r. o Rzeczniku Praw Obywatelskich, tekst jednolity: Dz. U. z 2020 r. poz. 627 oraz art. 10c ust. 3 ustawy z dnia 6 stycznia 2000 r. o Rzeczniku Praw Dziecka, tekst jednolity: Dz. U. z 2020 r. poz. 141. 
że „warunkiem udzielenia upoważnienia jest pisemne zobowiązanie się osoby upoważnianej do zachowania przetwarzanych danych osobowych w poufności". Jednak tego rodzaju wątpliwość ma jedynie znaczenie teoretyczne i konstrukcyjne, gdyż w praktyce z reguły czynności te są ze sobą ściśle powiązane i następują w tym samym czasie, a odmowa złożenia oświadczenia o zobowiązaniu do zachowania poufności, jeżeli byłaby dokonana po nadaniu upoważnienia, powinna skutkować odwołaniem upoważnienia.

Odebranie pisemnego zobowiązania do zachowania tajemnicy wiąże się zazwyczaj z koniecznością podpisania oświadczenia w postaci tradycyjnego (papierowego) dokumentu. W praktyce podpisanie tego rodzaju zobowiązania następuje często na dokumencie odnoszącym się do nadania upoważnienia, co sprawia, że również upoważnienia przybierają najczęściej postać tradycyjnego dokumentu. Nie oznacza to jednak braku możliwości przyjęcia innych rozwiązań przez administratora.

W wielu przepisach szczególnych prawodawca użył odmiennych od wskazanych powyżej w typowej konstrukcji sformułowań, co może być źródłem różnych wątpliwości i problemów. Na przykład w niektórych przepisach jest mowa o dopuszczeniu do przetwarzania danych osobowych wyłącznie osób do tego "uprawnionych" przy jednoczesnym nałożeniu obowiązku pisemnego zobowiązania do zachowania w poufności osób upoważnionych ${ }^{19}$. W niektórych przepisach jest mowa jedynie o upoważnieniu, bez określenia wymogu, że ma być ono pisemne ${ }^{20}$. W innych przepisach mowa o nadawaniu upoważnienia „w formie pisemnej w drodze imiennego upoważnienia, upoważnienia stanowiskowego lub aktu wewnętrznego, chyba że przepis szczególny stanowi inaczej"21. O ile niektóre wspomniane powyżej różnice są świadomym i celowym działaniem prawodawcy mającym na celu uwzględnienie specyfiki sektorowej i mogą być uzasadnione, o tyle niekiedy można odnieść wrażenie, że wprowadzone zmiany (w zakresie ich odmienności od konstrukcji typowej) nie mają merytorycznego uzasadnienia i stanowią świadectwo braku konsekwencji prawodawcy.

19 Por. m.in. art. 5a ustawy z dnia 17 czerwca 1966 r. o postępowaniu egzekucyjnym w administracji, tekst jednolity: Dz. U. z 2020 r. poz. 1427 z późn. zm.

20 Por. m.in. art. 84aa ust. 5 ustawy z dnia 7 lipca 1994 r. - Prawo budowlane, tekst jednolity: Dz. U. z 2020 r. poz. 1333.

21 Por. m.in. art. 15aa ust. 2 ustawy z dnia 13 października 1995 r. o zasadach ewidencji i identyfikacji podatników i płatników, tekst jednolity: Dz. U. z 2020 r. poz. 170. 
W praktyce wiele wątpliwości budzi również kwestia konieczności dokonania zmiany upoważnień wydanych wcześniej. Należy dokonać oceny upoważnień pod kątem ich zgodności z wymogami określonymi w przepisach szczególnych i w razie niezgodności konieczne może okazać się dokonanie ich zmiany. $Z$ reguły jednak dotychczasowa formuła upoważnienia zasadniczo odpowiada wymogom nowych przepisów i nie pociąga za sobą konieczności wymiany wszystkich udzielonych wcześniej upoważnieńn ${ }^{22}$. Warto jednak przygotować wzór upoważnienia dostosowany do obowiązujących przepisów i wykorzystywać go przy nadawaniu nowych upoważnień.

\section{Zakończenie}

Na podstawie przedstawionych w niniejszym artykule analiz można wyciągnąć kilka ogólnych wniosków dotyczących upoważnień do przetwarzania danych osobowych. W świetle przepisów obowiązujących przed unijną reformą ochrony danych nadawanie upoważnień do przetwarzania danych osobowych było powszechnym obowiązkiem administratora wynikającym z art. 37 uodo 1997 i mieściło się w granicach przyznanej prawodawcy krajowemu swobody implementacyjnej. Od momentu rozpoczęcia stosowania rozporządzenia 2016/679 (tj. od 25 maja 2018 r.) należy uznać, że zasadą jest swoboda decydowania administratora w zakresie tego, czy nadawać osobom indywidualne upoważnienia, czy też w inny sposób zapewnić przestrzeganie wymogu przetwarzania przez te osoby danych osobowych pod nadzorem i zgodne z instrukcjami administratora. Jednakże swoboda ta została znacznie ograniczona przez prawodawce krajowego poprzez uchwalenie przepisów szczególnych, w których przewidziany został obowiązek nadawania pisemnych upoważnień. Takie działanie prawodawcy może w praktyce skutkować tym, że zamiast dokonywać oceny, czy w świetle przepisów szczególnych istnieje obowiązek

22 Jeżeli zakres upoważnienia nie uległ zmianie, a wątpliwości odnoszą się jedynie do podstawy prawnej nadania upoważnienia (w upoważnieniu wskazany jest nieobowiązujący obecnie art. 37 uodo 1997), to nie ma potrzeby dokonywania zmiany upoważnienia, gdyż fakt zmiany podstawy prawnej nie wpływa na ważność upoważnienia, a treść upoważnienia w tym zakresie wskazuje jedynie na podstawę, na podstawie której upoważnienie zostało wydane. 
nadawania upoważnienia, wielu administratorów pozostanie przy dotychczasowej praktyce powszechnego nadawania upoważnień wszystkim osobom dopuszczonym do przetwarzania danych osobowych. Należy jednak podkreślić, że z przepisu art. 29 rozporządzenia 2016/679 nie wynika ogólny obowiązek nadawania indywidualnych upoważnień do przetwarzania danych, a w przypadku gdy przepisy szczególne takiego obowiązku nie przewidują, administrator może zastosować odmienne zabezpieczenia, aby zapewnić bardziej efektywną ochronę.

\section{Bibliografia}

\section{Źródła}

\section{Akty prawne}

Dyrektywa Parlamentu Europejskiego i Rady 95/46/WE z dnia 24 października 1995 r. w sprawie ochrony osób fizycznych w zakresie przetwarzania danych osobowych oraz swobodnego przepływu tych danych, Dz. Urz. UE L 281 z 23.11.1995, s. 31-50; Dz. Urz. UE polskie wyd. spec.: rozdz. 13, t. 15, s. 355-374 z późn. zm., uchylona.

Rozporządzenie Parlamentu Europejskiego i Rady (UE) nr 2016/679 z dnia 27 kwietnia 2016 r. w sprawie ochrony osób fizycznych w związku z przetwarzaniem danych osobowych i w sprawie swobodnego przepływu takich danych oraz uchylenia dyrektywy 95/46/WE (ogólne rozporządzenie o ochronie danych), Dz. Urz. UE L 119 z 4.05.2016, s. 1-88, ze sprostowaniem.

Ustawa z dnia 23 kwietnia 1964 r. - Kodeks cywilny, Dz. U. z 2019 r. poz. 1145 z późn. zm.

Ustawa z dnia 17 czerwca 1966 r. o postępowaniu egzekucyjnym w administracji, tekst jednolity: Dz. U. z 2020 r. poz. 1427 z późn. zm.

Ustawa z dnia 15 lipca 1987 r. o Rzeczniku Praw Obywatelskich, tekst jednolity: Dz. U. z 2020 r. poz. 627.

Ustawa z dnia 7 lipca 1994 r. - Prawo budowlane, tekst jednolity: Dz. U. z 2020 r. poz. 1333.

Ustawa z dnia 13 października $1995 \mathrm{r}$. o zasadach ewidencji i identyfikacji podatników i płatników, tekst jednolity: Dz. U. z 2020 r. poz. 170.

Ustawa z dnia 29 sierpnia 1997 r. o ochronie danych osobowych, tekst jednolity: Dz. U. z 2016 r. poz. 922 z późn. zm.

Ustawa z dnia 6 stycznia 2000 r. o Rzeczniku Praw Dziecka, tekst jednolity: Dz. U. z 2020 r. poz. 141. 
Ustawa z dnia 21 lutego 2019 r. o zmianie niektórych ustaw w związku z zapewnieniem stosowania rozporządzenia Parlamentu Europejskiego i Rady (UE) 2016/679 z dnia 27 kwietnia 2016 r. w sprawie ochrony osób fizycznych w związku z przetwarzaniem danych osobowych i w sprawie swobodnego przepływu takich danych oraz uchylenia dyrektywy 95/46/WE (ogólne rozporządzenie o ochronie danych), Dz. U. z 2019 r. poz. 730.

\section{Orzecznictwo}

Wyrok NSA z dnia 21 grudnia 2006 r., I OSK 1279/05.

Wyrok SN z dnia 4 kwietnia 2017 r., II PK 37/16.

\section{Literatura}

Barta J., Fajgielski P., Markiewicz R., Ochrona danych osobowych. Komentarz, Warszawa 2015.

Cwener M., Nowe obowiązi dokumentacyjne zwiazane z przetwarzaniem danych osobowych, w: Ogólne rozporzadzenie o ochronie danych osobowych. Wybrane zagadnienia, red. M. Kawecki, T. Osiej, Warszawa 2017.

Drozd A., Ustawa o ochronie danych osobowych. Komentarz. Wzory pism i przepisy, wyd. 3, Warszawa 2007.

Fajgielski P., Ogólne rozporządzenie o ochronie danych. Ustawa o ochronie danych osobowych. Komentarz, Warszawa 2018.

Krzysztofek M., Ochrona danych osobowych w Unii Europejskiej po reformie. Komentarz do rozporzadzenia Parlamentu Europejskiego i Rady (UE) 2016/679, Warszawa 2016.

Litwiński P., Barta P., Kawecki M., Rozporządzenie UE w sprawie ochrony osób fizycznych w zwiazku z przetwarzaniem danych osobowych $i$ swobodnym przeptywem takich danych. Komentarz, red. P. Litwiński, Warszawa 2018.

Sakowska-Baryła M., Prawo do ochrony danych osobowych, Wrocław 2015.

Witkowska-Nowakowska K., Komentarz do art. 29, w: RODO. Ogólne rozporządzenie o ochronie danych. Komentarz, red. E. Bielak-Jomaa, D. Lubasz, Warszawa 2018.

Wygoda K., Komentarz do art. 29, w: Ogólne rozporządzenie o ochronie danych osobowych. Komentarz, red. M. Sakowska-Baryła, Warszawa 2018.

Wojczys P., Pisemne upoważnienia do przetwarzania danych, Informacja w Administracji Publicznej 2019, nr 9.

\section{Streszczenie}

W artykule została omówiona problematyka upoważnień do przetwarzania danych osobowych w świetle przepisów ogólnego rozporządzenia o ochronie danych osobowych oraz krajowych przepisów szczególnych. Przedstawiono 
genezę wprowadzenia obowiązku nadawania upoważnień w poprzednio obowiązujących przepisach krajowych, zaprezentowano wykładnię obecnie obowiązujących przepisów dotyczących przetwarzania danych osobowych pod nadzorem i zgodnie $z$ instrukcjami administratora oraz ukazano wyniki analiz dotyczących krajowych przepisów szczególnych nakładających obowiązek nadawania upoważnień.

Słowa kluczowe: ochrona danych osobowych, upoważnienie do przetwarzania danych osobowych, art. 29 ogólnego rozporządzenia o ochronie danych osobowych

\section{AUTHORIZATION TO THE PROCESSING OF PERSONAL DATA}

\section{Summary}

The article discusses the issue of authorizations to process the personal data in the light of the provisions of the General Data Protection Regulation and specific provisions contained in the national regulations. In the article the genesis of the introduction of the obligation of authorizations in the previous national provisions is included, as well as the interpretation of the currently in force provisions regarding the processing of personal data under the authority of the controller and on instructions from the controller. Furthermore, the author presents the results of analysis of the specific national provisions concerning the obligation to grant authorizations.

Key words: personal data protection, authorization to process the personal data, art. 29 of the General Data Protection Regulation

\section{ДОВЕРЕННОСТЬ НА ОБРАБОТКУ ПЕРСОНАЛЬНЫХ ДАННЫХ \\ Резюме}

В статье обсуждается вопрос доверенностей на обработку персональных данных в свете положений Общего постановления о защите персональных данных и национальных специальных положений. Представлен генезис введения обязательства по выдаче доверенностей в национальных специальных положениях. Была изложена интерпретация применимых в настоящее время положений, касающихся обработки персональных данных под наблюдением и в соответствии с инструкциями администратора, а также 
исследовано результаты анализа конкретных национальных положений, налагающих обязательство предоставлять доверенности.

Ключевые слова: защита персональных данных, доверенность на обработку персональных данных, ст. 29 Общего постановления о защите персональных данных 